\title{
Co-determination in Germany: 1949-1979 and there beyond: bonding or compulsion?
}

Citation for published version (APA):

Backhaus, J. G. (1997). Co-determination in Germany: 1949-1979 and there beyond: bonding or compulsion? METEOR, Maastricht University School of Business and Economics. METEOR Research Memorandum No. 020 https://doi.org/10.26481/umamet.1997020

Document status and date:

Published: 01/01/1997

DOI:

10.26481/umamet.1997020

Document Version:

Publisher's PDF, also known as Version of record

\section{Please check the document version of this publication:}

- A submitted manuscript is the version of the article upon submission and before peer-review. There can be important differences between the submitted version and the official published version of record.

People interested in the research are advised to contact the author for the final version of the publication, or visit the DOI to the publisher's website.

- The final author version and the galley proof are versions of the publication after peer review.

- The final published version features the final layout of the paper including the volume, issue and page numbers.

Link to publication

\footnotetext{
General rights rights.

- You may freely distribute the URL identifying the publication in the public portal. please follow below link for the End User Agreement:

www.umlib.nl/taverne-license

Take down policy

If you believe that this document breaches copyright please contact us at:

repository@maastrichtuniversity.nl

providing details and we will investigate your claim.
}

Copyright and moral rights for the publications made accessible in the public portal are retained by the authors and/or other copyright owners and it is a condition of accessing publications that users recognise and abide by the legal requirements associated with these

- Users may download and print one copy of any publication from the public portal for the purpose of private study or research.

- You may not further distribute the material or use it for any profit-making activity or commercial gain

If the publication is distributed under the terms of Article $25 \mathrm{fa}$ of the Dutch Copyright Act, indicated by the "Taverne" license above, 


\title{
Co-Determination in Germany: 1949-1979 and There Beyond: Bonding or Compulsion?
}

Paper prepared for presentation at the Center for Law and Economics Studies

Columbia University, New York

22 November 1996

\author{
Jürgen G. Backhaus ${ }^{1}$ \\ Maastricht University \\ AE \\ Postbus 616 \\ 6200 MD Maastricht \\ Nederland \\ tel: $+31-43-3883652 / 36$ \\ fax: +31-43-3258440 \\ email: f.schijlen@algec.unimaas.nl
}

1 Thanks to Henry Hansmann and Stephen Bainbridge for helpfull comments and to Reginald Hansen, who provided many useful suggestions and pointed to new evidence. 
Co-Determination in Germany: 1949-1979 and There Beyond: Bonding or Compulsion?

\section{Introduction}

I. Antecendents: 1848, 1916, 1919, 1946

II. The Situation in 1949

III. Shifting Constraints 1946-1947-1948-1951

IV. Böhm's Critique

V. Co-Determination as an Interlocking System

VI. Legislation of Background Law and Deal Law

VII. Application to the Legislation of Co-Determination Structures

VIII. The Paradox of Monitoring

IX. The Solution: Bonding

X. Path Dependence: 1965, 1976, 1979

Conclusions 


\begin{abstract}
Co-determination refers to a set of rules and institutions which form an interlocking system and as such provide the unique structure of German corporate governance. This essay deals with the reasons responsible for bringing the structure about. In particular, the decision making process leading up to co-determination is carefully analyzed in terms of deciding the question, whether the participants were engaged in rent-seeking or in efficient legislation.
\end{abstract}

Key words: co-determination, decisions under uncertainty, strategic legislative choice, human capital accumulation, joint stock companies, demountation, performance of institutions

J.E.L. code: K22 


\section{Co-Determination in Germany: 1949-1979 and There Beyond: Bonding or Compulsion?}

\section{Introduction}

On October 22, the Wall Street Journal Europe ran the following story on Daimler Benz:

"Frankfurt - Top officials of Daimler-Benz AG will attempt to smooth out differences over the German company's future management structure today, but a final decision might well be delayed until next year, company officials said.

The routine meeting of Daimler's four men steering committee comes amid growing impatience among the company's management with the discord within their ranks.

Daimler Chairman Juergen Schrempp is championing a merger of the holding company with automobile maker Mercedes-Benz AG, its biggest unit, in order to streamline management and expedite decision-making within the group. Mercedes Chairman Helmut Werner and worker representatives reportedly oppose Mr. Schrempp's plans, arguing that they would slam workers' morale amid a critical drive to diversify its products and markets.

Neither Mr. Schrempp nor Mr. Werner would comment on the restructuring proposals, but Karl Feuerstein, chairman of Daimler's in-house works council and deputy chairman of its supervisory board, told the Reuters news service that Mercedes must under no circumstances be split up along business lines in any restructuring. "We will measure all proposals according to this demand," Mr. Feuerstein said. "We must discuss this comprehensively in the supervisory board. Maybe the decision won't be taken this year," he added.

Mr. Feuerstein is one of two employee representatives on the steering committee, which also includes Hilmar Kopper, the chairman of Deutsche Bank AG - Daimler's biggest shareholder with a $24.3 \%$ stake - and a lawyer who represents other financial backers of the group.

Both sides are said to be keen on keeping Mr. Werner behind the wheel at Mercedes, which provides $80 \%$ of the sales and most of the profits for Daimler, a transportation group with interests in aerospace engineering, telecommunications and financial services. German media have reported that Mr. Werner threatened to resign if Mercedes were to be swallowed by Daimler."

With a few broad brushes, the story shows how different is decision making in German corporate board rooms from similar processes elsewhere, for instance in the United States. To begin with, boards are split into two, the managing and the supervisory board. Works councils elect the powerful chairmen, who can end up on supervisory boards and more importantly, the steering committees. In addition, investment bankers may join forces with employee representatives in controlling management appointments. How did this system come about, which events shaped it, and why is it being continued by globally operating companies? In other respects, this same company has been a leader in introducing deep changes in the world of German corporations. Leading the way to being listed on the New York stock exchange and therefore obliging with the requisite SEC as well as EC rules on corporate accountability. In fact, the company now uses two competing accounting systems for the consumption of German and US stockholders respectively. 


\section{Antecedents of Co-Determination}

Co-determination has a long intellectual and legislative history in Germany. The issue was already discussed by the very first democratic German parliament which gathered in the Frankfurt Church of Saint Paul in 1848. Still during the First World War, the first legislative measures were taken. The Weimar constitution of post World War I republican Germany, in article 165, introduced co-determination both on the plant level as well as there beyond, as regional, industry wide and central councils were to be formed. The specific feature of adding labor representatives to the supervisory board was first established in an act passed on February 15,1922 . The notion of establishing councils carried through the ideas of the German November revolution of 1918 which led to the collapse of the German empire and the demise of German monarchies.

After the second World War, the situation was completely different. Not only the organizations of German statehood had collapsed, the country itself lay in ruins and her productive capacity had been largely destroyed with plants being damaged, the workforce dispersed and slowly returning often disabled, and an allied de-industrialization policy being added on top which found its most obvious form in the large scale demountation of German industrial infrastructure including plants, machinery and equipment, railroad equipment including tracks etc. In the population, there reigned a widespread belief that not only political forces were to blame for the catastrophe, but that, in addition, the economic constitution of pre-war Germany had enabled the political leadership to conduct its disastreous policies. As gradually a German statehood was re-establishing itself, the newly established states that would later form the Federal Republic adopted constitutions which typically established forms of worker participation if not outright socialization of industry, such as was provided in the constitution of the State of Hesse (article 41). This article transferred into forms of social property, the entire mining industries, companies being involved in the production of iron and steal, the entire energy sector and all forms of public transportation in the sense of requiring either rail or suspended power lines, such as an electrified railroad, a tram or a trolley bus. It is interesting to note that, since energy and public transportation were already in the public domain, the article supported by $71.9 \%$ of the voting population in a seperate referendum, has not only a socialist but also an anti statist slant. The mining, iron and steal industry, on the other hand, had previously been pre-dominantly private sector activities. From the point of view of codetermination, it is interesting to look at the corporate governance structures finally suggested in the organization act required by the constitution. The act foresaw two levels of corporate governance. At the plant level, control would be shared by representatives of the workers, representatives of the municipality where the plant was located and representatives of a state holding entity, to which all the socialized corporations belonged. This tri-partite representation was to be on equal terms. The holding entity, on the other hand, was to have a tri-partite governance structure again, with the first third of governors being elected by the Trade Union Federation of the State of Hesse, the second third being proportionately elected by the Federations of the State of Hesse of the Cities, the Counties and the Municipalities (a city being part of a county), and the remaining third being elected by the State Parliament on the one hand and appointed by the Ministries of Economic Affairs, Labor Relations and Finance on the other.

Two ideas clearly underlie this scheme of a corporate governance structure of the socialized key industries of the State of Hesse. The first idea is the notion of involving all kinds of stake- 
holders in the corporation, the workers, the local municipalities, the counties and cities i.e. all those that had to provide for the proper infrastructure in which the corporation was to thrive; the second idea is the notion that decisions be taken as much at the plant level as possible, with the entire set of socialized industries being subject to a very loose state guidance, which can only indicate but never direct (never more than one third of the vote). An idea prominently absent from this proposed set of governance structures is the notion that corporate governance could rely on markets, such as capital markets, markets for managers or other markets for corporate control. $^{2}$

\section{The Situation in 1949}

On August 14, 1949, the first parliament in West-Germany was elected. It had a large spectrum of parties, the Communists, the Social-Democrats, still pushing for a centrally planned economy, the Bavarian Party, the Center Party representing segments of the Catholic population, the Christian Social Union from Bavaria, the Christian Democratic Party, the Free Democratic Party standing for market values, the mildly conservative German Party from Lower Saxony continuing the long tradition of the "Welfen" [Ghibellines] in Hannover, the Federation of Refugees and the Dispossessed (BHE), the National Conservative All German Party and the Socialist All German Party, covering the spectrum from left to right. Later, the constitutional court would forbid the Communist Party and the Socialist All German Party as not operating within the premise of the Basic Law (Grundgesetz) of 1949. With a hair thin majority of one vote, the first Chancellor Konrad Adenauer was elected on September 15, who could be appointed by the new President who had just been elected on September 12. Thus, a broad center-right coalition government was formed which included as yet no Minister of Foreign Affairs. Even prior to electing a chancellor thereby forming a government, the Parliament had initiated its work by passing the following resolution introduced by the faction of the Social Democratic Party:

"Petition of the faction of the Social Democratic Party.

Reference: Demountations.

The Bundestag is requested to decide: The German Bundestag states that the continuing demountations prevent the reconstitution of the German economy and amount to an insupportable burden of the new democratic state....

The Bundestag hopes that the governments of France, Great Britain and the United States of America will expedite a re-examination of the demountation lists and, before a full review has not been completed, will stop the current demountations." 3

\footnotetext{
2 For further references and documentation of this example, see Jürgen Backhaus, "Die Überführung von Produktionsmitteln in Gemeineigentum", Zeitschrift für öffentliche und gemeinnützige Unternehmen, 18.4, 1995, 465-476.

3 Printed matter nr. 2, German Parliament [Deutscher Bundestag] 1, 1949.

The term "demountation" refers to the dismantling or disassembling of industrial plants. According to allied agreement, Germany was to be demilitarized, and this could be interpreted by removing its productive capacity. Lists of militarily relevant productions sites had been drawn up, and demountation teams were systematically implementing the policy by following these lists.
} 
The grim climate in the industrial heartlands of Germany in the Fall of 1949 is well expressed by the communist MP Paul, who even speaks of an accelaration of demountation efforts and conflicts between the demountation teams and the workers at these sites so fierce that in the case of the Gelsenberg mine both state and local police had to get involved. But the issue remained beyond the jurisdiction of the parliament, which is why in this instance the matter was referred to the parliament's committee on occupation and foreign affairs. ${ }^{4}$

This forms part of the back drop for the unusual petition on the part of the joint faction of the Christian Democratic and Christian Social Union asking the government, of which these parties were the two leading partners, to introduce legislation covering the legal relationships between workers and employers in accordance with the coalition program introduced in the parliament on 20 September 1949. The new legislation was to replace the works council legislation of the Allied Control Council as well as state legislation and introduce "according to an order that befits our times, the co-determination right of workers once and for all". 5

What may have driven this unusual petition - the leading faction petitioning its own administration to introduce a piece of legislation that only weeks ago it had formally announced as a priority? At first blush this is by no means obvious. In presenting the petition, the speaker for the joint faction of the Christian Democratic and Christian Social Union, first offers a historical review of German co-determination starting in 1920. He then puts forward a reason that is suggested to have triggered the initiative. The Allied Control Council had passed with act nr. 22 a framework legislation which, in the different zones, had been implemented differently. These implementation rules were, however, suspended by the allied powers as having become the prerogative of the newly established German parliament. Thus, a kind of legislative vacuum had been created, which the Christian Democrats saw a need to fill. He concluded by strongly arguing for the continuation of those institutions in which the labor representatives in recent times had shown their ability to take responsibility for economic decisions. ${ }^{6}$

The ensuing debate involved speakers of the Social Democrates, the Communists and the (promarket) Free Democrats. All three speakers supported the initiative. On the left side, the Communists preferred, however, building on the provisions of the state constitutions, of which we have already noted the Hessean example. The Social Democrats squarely supported the initiative, and also the speaker of the Free Democrats did so. In the margin, he noted that even without this initiative, the government would shortly have introduced the relevant legislation, and that, although he broadly supported the idea of co-determination, there was room for disagreement about details. Yet, specifically, he mentions both the institutions of works councils and the general notion of co-determination ("Mitbestimmung") as what his party intends to support. Petition nr. 117 then passed with an "overwhelming" majority.

The details proved to be thorny indeed. It took more than a year until, on February 9 1951, the Chancellor introduced an act about the co-determination ("Mitbestimmung") of workers in companies in mining and iron and steal production, on the same day that the Bundesrat, the

\footnotetext{
$4 \quad$ German Parliament 1 (1949), 15th session of 4 November 1959, p. 352

$5 \quad$ Printed matter nr. 117, Deutscher Bundestag 1, 1949.

6 German Parliament 1 (1949), 15th session, 4 November 1949, p. 353.
} 
representation of the states that constitute the Federal Republic, had passed the government's draft act. The Bundesrat then acted under the chairmanship of the Prime Minister of the State of Northrhine Westfalia, the location of the West-German industrial heartlands. The chairmanship of the Federal Council (Bundesrat) changes routinely on a bi-annual basis between the Prime Ministers of the Federal German States. Accordingly, the chairman acted within weeks of assuming his position.

The animated debate on February 141951 extends over some 30 pages of the official register. $^{7}$ The entire specter shows a sense of great haste. The chancellor himself introduced the act, being interrupted several times, mostly by the Communists but also from the right. He variously receives applause from the Social Democrats, his own faction and, according to the minutes, a not clearly specified "right". The official motivation for the legislation was still lacking, it had not yet been printed and distributed. The members of parliament worked on the basis of the printed draft act, the changes requested by the Federal Council and the oral presentations. After the chancellor, the Minister of Labor Relations (responsible for this legislation) read the official motivation but dared not depart from the written text which provoced sarcastic criticism from the Social Democrats (Dr. Schumacher).

The Chancellor's speech consists of essentially three points. He first explains the circumstances under which the legislation had been introduced. The Minister of Economic Affairs, he says, when asked in a committee about the future representation of workers in the mining, iron and steal industry, once Allied legislation would have to be substituted by German legislation, had given an answer that had led worker representatives, but in particular the trade unions to the conclusion that he wanted to take away from them the rights they now possessed. Although, the Cancellor says, the Minister of Economic Affairs strongly denies that what he intended to say could have been interpreted this way, "this restlessness has spread and led to those notices (of labor agreements of trade unions and companies) being served that first occurred in the iron and steal industry, later in mining." (p. 4431) Before a strike can occur, under German law these notices have to be served. The Chancellor continues by pointing out that from the very start he had pointed out that this not being a dispute in the realm of collective bargaining, a strike "against the constitutional body of legislation" could not be allowed to take place. Yet, the Chancellor said, he had also pointed out how in his experience the policies of the German Trade Union Congress had always been moderate.

Secondly, the Chancellor reviews the recent history of worker representation in the mining, iron and steal industry, notably in the Rhineland and Westfalia. He emphasizes the rights granted to the worker representatives there, and by the occupation powers, by act of 1947 , emphasizing that it was a specific not a general arrangement. Finally, and in conclusion, the Chancellor emphazes the important role workers and the representatives have played in fighting the demountations. On numerous occasions, the Chancellor points out, has he been impressed by the deep affection the workers had displayed towards their plants.

A central feature of German post World War II co-determination is its strict reliance on the two tier system as far as the aspect of corporate governance is concerned, next to the system

$7 \quad$ German Parliament 1 (1949), 117th session, 14 February 1951, pp. 4431-4460. 
of works councils that, of course, emphasizes issues of plant organization. Obviously, most corporations in this range comprise many different plants with many different work related arrangments and challenges. The mountain and steal related co-determination act of 1951 is different in that, next to the supervisory board of the corporation, also the managing board has an element of worker representation, in that one of the at least three managing directors, the one with personnel and labor relations in his portfolio, is to be appointed with a majority of the votes of the worker representatives on the supervisory board, and he is to work on equal terms with his colleagues in the governing board. The most interesting portion of the speech by the Labor Minister, who was in charge of this legislation, concerns this very point, and he was actually pressed by the chairman of the Social Democratic Party to emphasize and clarify the position of the so-called Labor Director (Arbeitsdirector) which he did.

The parliamentary debate of the act (in the first reading) lasted for only three hours. Yet, all the relevant arguments necessary to explain co-determination as a result of the specific conditions in Germany were made. In what seems to be a generous use of arithmetic, the speaker had assigned 36 minutes to each of the major factions and 15 to each of the smaller factions, there being only two major factions, the Social Democrats and the joint faction of the Christian Democratic and Christian Social Unions. The speaker for the Social Democratic Party, Mr. Imig, started the debate with an interesting review of the recent history of co-determination. He revealed that on January 19, 1947 Dr. Jarres, the chairman of the supervisory board of the steelmaker Klöckner, suggested to the trade union (here the metal union) the following: "We here at Klöckner think that a new arrangement must be found for the iron industry that fits the changed times: and that there should be a practical parity, i.e. an equal representation, but also equal responsibility of capital and labor." Specifically, he wanted to realize this parity in the supervisory board of the Klöckner works. ${ }^{8}$ On the same day, a similar suggestion was made by Dr. Reusch and Dr. Hilbert, both members of the board of the Gute Hoffnung mine. And thirdly, on January 21, 1947, Dr. Hillman of the steel company Otto Wolff followed suit.

Secondly, the speaker points out that co-determination is also about political control, as the workers have not yet forgotten that the product of their work had been used against themselves, suggesting that at least the last war could have been prevented had codetermination already been introduced.

And thirdly, he points out that the workers, on the basis of the Allied acts number 75 and number 27 have gathered the requisite experience that they would now need.

Different speakers of the Christian Democrats added no substantively new information. The first speaker emphasized a broad consensus on which the act had been based, the issue of parity, again, and the solution to realize this parity in the supervisory board. Later, a second speaker of the Christian Democrats, himself the member of a supervisory board of a mine in Haspe confirmed the account of the origin of the co-determination idea and added that the Allied policies of de-composing large conglomerates (Entflechtung) had also played a role in this decision (p. 4446). The first speaker of the Christian Democrats, by the way, has this interesting sentence in his remarks: "A sensible application of co-determination can, as we know from experience, increase both productivity and the credit worthiness of the corporations

$8 \quad$ German Parliament, 117th session on February 4, 1951, p. 4436. 
concerned". (p. 4441)

The speakers of the Free Democrats, a coalition partner, were the most critical of the codetermination initiative. Points of interests are the idea that there may be a certain tension with article 14 of the German Basic Law which guarantees private property, that the strike threat by the unions puts the parliament under duress and that article 105 of the penal code would therefore be relevant, but also, and importantly, one of the speakers (Dr. Becker) outlines the following essentials of the Free Democrats with respect to co-determination:

1. Complete co-determination in all social matters;

2. Participation in hiring and firing;

3. Consultation in all economic affairs in commissions of which thirty per cent are labor representatives;

4. Thirty per cent of labor representation on the supervisory boards;

5. All labor representatives must be employed in the firm itself (i.e. no external trade union representatives).

We see then, that even the most pro-market political party supported co-determination to a very large extent.

A speaker of the Christian Social Union (Dr. Semler) quoted the constitution of his home state of Bavaria which requires co-determination in support of his own support of co-determination. A speaker for the mildly conservative Ghibelline German Party supported co-determination above all with a view to social peace. A speaker for the Bavarian Party was not critical of the act itself, but of the trade union tactics that had brought it about and he was anxious to avoid a repetition of this scenario. The speaker for the Catholic Center Party found that codetermination was the basic requirement for a new social and economic order. The speaker for the Federation of Refugees and the Dispossessed emphasized the "divine right to private property" and therefore was critical of the role of the trade unions, rather wishing more coentrepreneurship. The speaker of the Socialist All German Party linked the notion of codetermination and participation in the company profit: in a crafty mélange of different facets, he was trying to emphasize discord in the governing coalition. Similarly, the member of the Communists (Agatz) places the act already in the context of the Cold War and a possible German re-armament, but he also quite accurately depicts the way how the workers and their representatives took an active part in the post war reconstruction of not only plants but also corporations. He feels that co-determination is a way to engage workers in the firms so that they find their co-determined companies worth defending (p.4458) implying, that this might be a military defence.

Finally, the arch conservative speaker for the All German Party also emphasizes codetermination through co-entrepreneurship and is likewise critical of the role ascribed to the trade unions in the draft act.

After the debate is over, apparantly reasonably on time, there is a certain amount of procedural manouvering. It is, however, noteworthy that a speaker for the Free Democrats, "in the interest of expediting the procedure" (p. 4460) suggests to send the draft act only to two committees, the Committee for Finance and Tax Matters (in the United States the Ways and Means Committee) and but in a subordinated way, to the Committee of Justice. This proposal is then accepted without any dissent. The final act passes with an overwhelming majority, 
(some fifty votes not being cast in its favor).

\section{Shifting Constraints 1946-1947-1948-1951}

The sequence of events in post World War II Western Germany is then characterized by the following legal events. In 1946 most of the re-constituting states passed constitional documents, and most of these documents contain some provision of co-determination. In 1947, various academically trained industry leaders, and we know of at least four, for their respective industries in coal, iron and steel suggest that there be a parity representation of labor and capital in the supervisory boards of the respective companies. This is still under the conditions of an administered economy with no workable currency in place and no access to international capital markets, actually no prospect for any type of capital investment in sight. In 1948, there is the currency reform and, gradually, markets develop which means that companies can sell their products and have a claim on resources in return, not a claim on resources as a consequence of a plan document. At this point, the consensus on co-determination begins to get certain fissures. At least the Free Democrats, still in principle supporting co-determination, think of market based forms of participation. Various groups in society are wary of the strong power of the trade unions, this being strong political power but also economic power through the institutions of co-determination. In 1949, however, the government immediately announces its intention to introduce co-determination by act of parliament, and it is encouraged to do so by its own leading coalition partner, the joint faction of the Christian Democratic and Christian Social Union.

In 1950 at the end of the year, and apparantly in early 1951 in the middle of the winter, the metal workers' and coal miners' unions threatened to strike if co-determination were not finally passed, at least for their industries. The parliament obliges, and the act is passed with an overwhelming majority.

In this way, the law and economics interpretation of co-determination can take two completely different directions. On the one hand, we could think of the German parliament, still a very young democratic institution, to be forced by the trade unions who were politically strong into a situation whereby they had to decide under duress. A strike threat in the middle of the winter, and memories of the bitter winter of 1946 still being fresh, was no light matter. On the other hand, however, the parliament obliged swiftly: the relevant debate takes only three hours, all parties agree that time is of the essence, and little criticism of the compromised draft act is actually voiced. More significantly, there is no alternative to the legislation proposed. No alternative organisation model is seriously being discussed that would satisfy the conditions reasonably unanimously detailed by all the relevant parties. The parliament was not exactly rubberstamping the proposed legislation, but the speakers did not argue from different legislative designs in order to criticize the draft. This insight begets the notion that the act may, under the circumstances, have essentially been without a conceivable alternative. The remainder of this essay is devoted to exploring this possibility.

In order to do so, let us return to the parliament, still in 1951. There was an episode to follow, which was to mar the entire carefully erected edifice.

An interesting afterplay occurred when the social democratic faction in an interpellation with respect to the performance of the Federal Minister of Justice asked the Federal Government to 
state whether the Minister of Justice, "in either the towns of Goslar or Uslar" had described the freshly passed co-determination legislation as an expression of injustice and suggested that the trade union leaders should be put in jail. The Social Democratic faction asked the government to answer whether 1. the Minister of Justice had said such things and 2. whether the government subscribed to his views. ${ }^{9}$

As the reader recalls the Free Democratic Party, along with other parties, had all along complained about what they described as duress under which they felt being put by the threat of strike in the coal industry: notably as that had happened during the winter, and the consequences of yet another winter without coal, just as the winter of 1946, were still very fresh in people's memories. Keep in mind that at the time both heating and transportation were dependant on a regular supply of coal, and lack of heat and food during the winter surely meant death for many citizens. The Chancellor himself, in introducing the legislation, had pointed out that he had rejected the threat of a strike already in December, but according to the record it had been repeated sometime in January. During state election campaigns in Lower Saxony, the Minister of Justice campaigning for the Free Democratic Party referred to this recent experience. Under the penal code as cited above, a jail sentence is required for whoever puts a legislature under duress. In introducing the interpellation, the speaker for the Social Democratic Party, after reviewing the history of co-determination under Allied control, says this: "What did the workers in the coal and steel industry actually do? In 1945, they were willing to take full responsibility, they were ready to re-construct our heavily damaged key industries. When their responsible positions in these industries were all of a sudden becoming uncertain, they served notice of their labor agreements to their social partners (the employers) if these social partners would withhold their co-determination right in the future. Is a worker violating the law, if he wants to continue his work only under the condition that he, through his trade union, can be a partner through co-determination in the enterprise? Is the Minister of Justice for forced labor under feudal conditions?"10

Indeed, nothing new was revealed during the debate except for the fact, that the Minister of Justice stood by his words. He, and many others who had campaigned in Northern Germany at that time felt that the minister was in his right, as a campaigner, to say what he had said. The fine line between what the minister bound by the Coalition Agreement and the party campaigner can say was clearly brought out in parliament.

Little new emerged from this discourse. After the final speaker, the arch conservative von Thadden, then the youngest Member of Parliament, had spoken, the speaker declared the agenda "exhausted", prompting calls from the center "for heaven's sake, we too!" (p. 5595) without further ado, the matter was disposed.

\section{Böhm's Critique}

All these debates did not occur in an intellectual vacuum. There was a lively political and literary culture.

There is, in particular, no want of critics of co-determination. Only the most intelligent

9 As printed matter number 2168 still of the first period of the German parliament 1949, submitted on April 18, 1951.

$10 \quad$ German Parliament, 140th session, 9 May 1951, p. 5587. 
critiques should be dealt with carefully. After all, co-determination has served one of the less likely leaders of the industrial world, after two crushing defeats on the battle field, well in regaining its own.

On the face of it, the scheme is an unlikely one. In order to explore the background of its inception, its story can also be told against the background of one of its most fervent critics: Franz Böhm. Böhm's influential study however is the often cited complete misunderstanding of what co-determination is about from an economic point of view.

Franz Böhm was not only a scholar, he was also a politician. He left his chair at the University of Freiburg for a chair at the University of Frankfurt, because he felt that Frankfurt would provide him with better chances for political influence. The massive contribution on codetermination, which was published in the scholarly yearbook ORDO, it dominated that year's edition, running over 229 printed pages, can be variously regarded as a scholarly or as a political contribution. I tend to see it more as a political contribution in scholarly disguise. It is not illegitimate for a lawyer to present political arguments as scholarly arguments. Böhm could be a skillful, shrewed and unusually determined politician who would resort to any means available to him in order to further his course. His finally successful negotiations intended to lead to a reconciliation between the German and the Jewish people give ample evidence of Böhm's character in this respect. Even where we do not agree with him, we should respect the sincerity of his convictions and look for the merits of his arguments.

Böhm is unusually critical of the institution of co-determination, associating all kinds of ills with it, but almost completely neglecting the positive effects co-determination was expected to have by those who brought the institution about.

It is for this reason sensible to again look at the origin of co-determination as a legislative proposal, since this is the background against which Böhm wrote his article in 1950.

The free German parliament in the three western zones of Germany that were constituted as the Federal Republic of Germany had barely met, when - this is the second printed matter of the entire parliamentory proceedings - on September 7, 1949 the faction of the Social Democratic Party introduced a petition to the governments of France, Great Britain and the United States to re-examine the demountation register, not to consider further demountations and to stop the currently ongoing demountations. The demountations of industrial sites, according to the parliamentory record, had been intensified during recent months and there had been violent clashes between the workers who were seeking to defend their machines against the demountation teams that were, by taking down and shipping away the machinery, destroying their working places. Luddites in reverse gear!

It is important to know that this practice was still going on in the industrial heartland of the German Federal Republic, the Rhine-Ruhr region, in the Fall of 1949 after the new state had already been constituted.

Against this background, we have to see the motion seemingly superfluasly being introduced by the faction of the Christian Democratic Union, to which the first chancellor belonged, to ask the government to prepare a co-determination act pursuant to the government program that had just been presented by the chancellor and defended in parliament. This motion, printed matter number 117, is dated October 1949. The purpose of such legislation was to override state legislation which had been halted by Allied decrees (issued by the Allied Control Council) which has precedence over German law, even over German constitutional (state) law. The motion received a large majority, being in fact supported by all parties from the very left (the Communists to - located on the right wing - the liberals (the Free Democrats). The Free 
Democrats emphasized substantial differences in opinion about what co-determination rights would finally be established, but they supported the government move. The Communists, while supporting the government in its move, preferred immediate implementation of the state legislation which had been halted by Allied decree.

At that time, Böhm, who was a member of the Christian Democratic Union, was not yet a member of the Bundestag. He became a member of parliament in 1953 in the second legislative period.

If we read Böhm's article from today's point of view without taking this historical background information into account, we cannot really understand why co-determination was ever introduced in Germany. As a matter of fact, Böhm himself postulates (page 143) that the vast majority of the people in their capacity as consumers, subjects under the private law and citizens is opposed to co-determination if only they understand what it is. On the other hand, he sees the unions and the entrepeneurs (I believe he means the managers) as supporters of codetermination, while the workers to the extent that they are not directly involved in codetermination are seen by Böhm as indifferent. Interestingly enough, he talks about codetermination of workers in the firm, when indeed co-determination was always supposed to take place at the corporate, not the plant level.

The heated debate in the first German parliament, which preceeded the introduction of codetermination, is somewhat at variance with the unanimous support of the measure as such. In fact, the debate never touched on any of the important issues of how to craft a proper governance structure for those companies that where supposed to be the parts in the engine of growth but should pull Germany out of distress and into democracy and prosperity. Today, if we look at the minutes of the parliamentary sessions, we cannot even see where the conflict could conceivably have been located. The heated rhetoric has a thoroughly empty-taste. In fact, no alternatives where ever presented in the parliamentary debate except for the summary reference by the Communists to the state constitutional legislations and here notably to the legislations of the state of Hesse and its socialization article of 1946 and its failed socialization act of 1948. Despite the richness in the German literature on different organizational models for corporate governance, no such alternative landscape had been provided for discussion in the German parliament when co-determination was passed. The stilted conflict over supposed remarks by the Minister of Justice, when the opposition could not even decide where these remarks had actually been made, shows clearly that bones were to be picked that had their origin in a different barn yard.

Having reviewed this parliamentary record in considerable detail, the question that arizes is this: Why, if there is such a wide spread agreement about a particular piece of legislation, is there such hefty debate in parliament at all? Clearly, the speakers were not posturing, they were speaking about clearly identifiable matters that mattered.

Part of the parliamentary record can be explained by the large diversity of factions. The spectrum of political views, after the shattering defeat of Germany and the splintered structure of its stathood was still very large. How, otherwise, could the Ghibelline Party have its own representation in parliament? Similarly, the Center Party or the Bavarian Party? Secondly, the appeal of those who had suffered under National Socialism, next to those who had suffered in their health often visibly by missing limbs was strong. The leader of the Social Democratic Party had to be supported by an aide as he moved to the podium. Sound minds in badly 
wounded bodies were in fact discussing the future of German economic order. Yet the interesting thing is that while they were in large agreement about the future of the German economic order, there is a substantial extent of agreement between the far right and the far left comprising the entire middle including the Free Democrats; the heavy handed tactics of the metal trade union, then calling the shots in the trade union congress on the one hand, against the background of the heavy handed tactics of the demountation commissions on the other gave the entire debate an issue dimensions which otherwise it would never have had. The underlying issue, noticable only upon reflection, is the emergence of markets in the recently established western part of Germany. Interestingly, in introducing the legislation, the chancellor blaims his own Minister of Economic Affairs for having caused the "restlessness" (i.e. the threat to strike in the core industry), and then immediately starts to defend his own minister, without this minister ever being heard in this debate. The Minister of Justice, who also had qualms about the legislation, vented his views likewise not in parliament (only after the interpellation) but rather during campaign speeches in Lower Saxony. If there was so much consensus, and since the demountations indeed soon stopped in the western part of Germany, what was the disagreement about? The answer is patently obvious, and it is also the answer that explains why the Minister of Economic Affairs did not even have to raise his voice. Under Allied Control, there in fact was no monetary economy. The allied forces had imposed a strict system of a planned economy, stringenst regulation and a system of allocations and allotments. Upon this system could thrive a class of people, called "functionaries" who were dealing odds that sometimes could be decisive of life or death. This system, coupled with the de-nacification attempt, bred widespread discontent and a support of market principles even in quarters that never had thought of markets very fondly, let alone deeply. In 1948, with the introduction of the new German currency, Ludwig Erhard, the silenced Minister of Economic Affairs, at a stroke introduced with the new currency also an at that point still rather limited access to world markets, but with this introduction the possibility of attracting investment. Indeed, the attractiveness for investment turns up in the legislative debate about the first co-determination act, although the speaker doesn't quite know how to handle it. Clearly by surprise, the Labor Union Movement was caught with the advent of capital markets. The threat of a strike by the ailing leader of the Trade Union Movement, Hans Böckler died shortly thereafter, did not change the course of the legislation any it; did only change the tone of the debate and it gave some fringe parties arguments which they used astutely, to the embarassement of the Minister of Justice who happened to have to campaign against these very arch conservatives in Lower Saxony.

Yet the deeper point was that with markets emerging, responsibilities had to be defined more clearly. No longer could you model management as some kind of ruling group in the corporation. Responsibilities between the Supervisory Board, the Managing Board and the Works Councils had to be clearly circumscribed. Dealing with coal shipments to preferred constituancies had to end, since coal now had a price, a market price that would bear on the bottom line and thereby on the ability of unions to extract wage concessions.

The upshot of these shifting constraints is aptly demonstrated in the parliamentary orchestra. The chancellor in acting on his guideline competence gives a general and very informative speech. The Minister of Labor Relations, clearly unhappy about his role, does not dare deviate one inch from his prepared speech. Upon criticism by the chairman of the Social Democratic Party, he even insists that the legal matters are so involved that he wants to stick to his text. 
Yet the Minister of Justice is not even heard in the debate until after the fact. And the Minister of Economic Affairs, who set all this in motion according to the chancellor's account, is nowhere to be seen. Yet, by setting it in motion, he could furthermore remain silent, because he understood the order of the market economy and how the cards would ultimately be dealt. In this context, the special position of the mountain industries also needs special attention.

\section{Co-Determination as an Interlocking System}

Co-determination is an interrelated set of institutions which consists of five major elements. Co-determination at the plant level involves the re-presentation of workers in works councils. Works councils need to be heard in many matters referring to the daily practice of work, they need to be involved in discussions with respect to such issues as hours, time and form of payment, hiring and firing of individual workers. They need to agree in economic matters that existentially concern them, in particular if a plant is to be closed. In that case, a social plan needs to be implemented. Obviously, the works councils have no say over what is being produced, what the prices are, what kinds of investments are being taken and so on. But what is crucial: they determine the exit costs and thereby the entry costs of a potential investor.

Next to the works councils, co-determination provides for the re-presentation of labour representatives on the supervisory boards of corporations. The supervisory boards appoint management and supervise management activities. Under different co-determination acts, workers have either one third or one half of the seats of the supervisory board. In the supervisory boards, the long term investment plans of companies are being determined. Thirdly, co-determination may involve the appointment of one member of the managing board of the company, who is in charge of personnel affairs and has the special trust of the labour representatives on the board. In this and only in this sense, labour can participate in the managing of some corporations, but the personnel director will always be in the minority. Under German corporate law, the board acts jointly.

\begin{tabular}{|l|l|l|l|l|l|}
\hline & Works Council & $\begin{array}{l}\text { Collective } \\
\text { Bargaining }\end{array}$ & Two Tier Board & $\begin{array}{l}\text { Bonding of } \\
\text { Investment }\end{array}$ & $\begin{array}{l}\text { Competition } \\
\text { between } \\
\text { Locations }\end{array}$ \\
\hline Works Council & $\mathrm{x}$ & 1 & 2 & 3 & 4 \\
\hline $\begin{array}{l}\text { Collective } \\
\text { Bargaining }\end{array}$ & 5 & $\mathrm{x}$ & 6 & 7 & 8 \\
\hline Two Tier Board & 9 & 10 & $\mathrm{x}$ & 11 & 12 \\
\hline $\begin{array}{l}\text { Bonding of } \\
\text { Investement }\end{array}$ & 13 & 14 & 15 & $\mathrm{x}$ & 16 \\
\hline $\begin{array}{l}\text { Competition } \\
\text { between } \\
\text { Locations/ } \\
\text { Gewerbesteuer }\end{array}$ & 17 & 18 & 19 & 20 & $\mathrm{x}$ \\
\hline
\end{tabular}


The acts establishing co-determination in Germany were passed by the German federal parliament in 1951, 1952, 1965 and 1976. The 1976 act, for instance, which generalized the co-determination model, which had originally in its strong form been only confined to the socalled "mountain" industries (mining and steal), carried a majority in the parliament of more than $90 \%$. In the context of European Union harmonization attempts of corporate law, Germany is trying to introduce co-determination as an element into European corporate law; this is being resisted by some other European Union Members. The reason for Germany's stance in this matter is the fact that co-determination is part of the German consensus and departing from it is not supported by any one of the stronger political movements in the country.

From a law and economics point of view, the question remains why Germany opted for this peculiar form of company organization, which is at substantial variance with the classical model of the business firm. The answer to this question has to be given in two parts. Part one of the answer needs to address the issue of why co-determination was introduced in the first place. Part two of the answer needs to address the issue why co-determination is being clung to as a generally desired form of corporate organization.

In 1949, Germany still lay in ruins. The reconstruction effort had not really taken off, because the institutional pre-requisites (stable money, stable legislative framework, labour peace, a supporting tax system and consistent economic policy) were not yet quite in place. Co-determination was one aspect of this package of implementing the institutional prerequisites for the reconstruction of post-World War II Germany. Since the physical plants had been largely destroyed or were still subject to demountation, productive capital was actually embodied in human capital. The human capital, of course, needed to be won over in any investment decision. It is for this reason that human capital was systematically introduced into the organized forms of capital representation in the corporation. Only in this way did it seem possible to re-invest unpaid wages and dividends into the company. In 1951 and in 1952 pursuant to the government program, West-Germany introduced the system of codetermination as we now know it. It was chosen over a number of different organizational alternatives which would all have been much less compatible with the functioning of a market economy. In 1965 with the reform of the act on joint stock companies, co-determination was again expanded into sectors not hitherto covered. It was further expanded in 1976. The legislative record is completely at odds with Böhm's predictions. It is difficult to conceive of an interest group driven scenario of parliamentary legislative decision making that could explain the consistency of the record and the large supporting majorities. The system has clearly proven workable, but it has interesting implications with respect to which industries can expand in Germany and which are driven abroad typically with the active co-operation of the labour representatives on the supervisory board - Volkswagen do Brasil probably having been the first highly visible example of the approach. In a nutshell the system is geared towards company structures with a near parity of human and physical capital. Only some lines of production lend themselves to this model, and herein lies a clear strategic choice of the codetermination legislation, although it may not have been consciously made.

Co-determination as a model cannot be superimposed on any country. Legislators keen on copying Germany's legislation should carefully consider Böhm's argument in order to find out 
whether the conditions that prevailed in Germany and made co-determination worth while a legislative experiment would prevail in the candidate country as well. Otherwise, Böhm's warning might well be heeded with profit.

In reviewing the parliamentary debate in 1951, one is surprised to note how little time was spent to hammer out the details of the legislation. Indeed, much of the relevant knowledge was probably shared by the members of parliament, but it was going to take almost thirty years until, in 1979, the German Constitutional Court emphasized the extent to which the different institutions making up the German co-determination system are interdependent, even interlocking. ${ }^{11}$ The system makes sense only, because its five different pillars support each other, taking one element away can result in serious shortcomings. The five elements have been listed in the matrix above, and their interdependance will be discussed in turn in the sequence of the numbers indicated.

The works councils are the oldest element, they were introduced during the First World War originally in the ammunition industry in order to allow workers, who threatened to strike, to participate in decisions about the organization of their working environment, schedules and the like. Today, the works councils are an omni-present part of the management structure of the German company. They are also present in the public service with slightly different functions, since civil servants in Germany do not have the right to strike.

1. The works councils relate to the institutions of collective bargaining in terms of the division of tasks. All those aspects works councils deal with are, in principle, not subject to collective bargaining. For instance, collective bargaining will set the base wage. Works councils will discuss with management when and how the wage is paid. This division of the task is extremely important since works councils, in order to be effective, have to be able to reach their goals by convincing management of the superiority of their proposed solution in the interest of the entire company. Works councils participate in decision making in the sense that they cannot be ignored: rarely can they take decisions on their own. Only in one case (when the firm is to be liquidated) can works councils by withholding their agreement to the social plan, impose a serious damage on the firm's owner. The institution of collective bargaining, on the other hand, by definition uses powerful sanctions on either side. The workers can strike, the companies can lock them out. In both cases, serious losses can be imposed. Unions may not be able to strike because they may not be able to pay the striking workers their compensation which typically they are understood to do. This division of tasks is extremely important in particular as we compare the German situation to the American one. In the United States, collective bargaining will also cover work rules, a practice which can result in very formalistic agreements about which disputes are likely to arise. On the other hand, union leaders used to collective bargaining may find it difficult to co-operate in company boards when given the chance, such as in the case of Eastern Airlines. (under the chairmanship of Frank Bormann)

2. The works councils are often the recruting ground for the labor member in the supervisory board of German co-operations. It is here where we realize that the two tier system is a precondition for co-determination to be possible. If the works councils were to send representatives into the managing board, they would end up negotiating with themselves. Incidentally, the labor directors mentioned above where always recruted from the outside in

11 BundesVerfassungsGerichtsEntscheidung (BverfGE) 50, 1979, 290. 
order to avoid such a conflict. By being able to rely on the works councils, the supervisory boards have a second channel of information at their disposal, the first one being management which, as they also have to control it, maybe withholding information that could be damaging. It is for this reason that the system of co-determination can strengthen owners' rights in the firm, at the expense of managers. In this sense, co-determination is one conceivable answer to the problem posed by Berle and Means.

3. Bonding is a device to protect sensitive investments into specific assests. When highly specific human capital is deployed in the production process, the owners may be interested in seeking protection against the loss that can occur if inappropriate management decisions are being taken. The works councils can provide such protection on the one hand through the day to day consultation with management, on the other hand through their links with the supervisory board. Here, both labor and capital can seek to protect the value of the investment by monitoring management that, through its operation, determines the marginal productivity of both capital and labor.

4. In Germany (as in the United States) local communities depend for their tax revenue on the profitability and presence of corporations within their jurisdiction. There exists a symmetry in the interest of the local communities and the employees of corporations, who typically are tied to these communities by virtue of their home ownership, family and other ties and generally their roots. German workers tend to be much less mobile than their American counterparts. Thus, the works councils also act in the interest of the local communities from where they stem in garding the presence of the corporation at its current location. This, by the way, does not prevent co-determined firms from making sometimes large investments overseas, if these investments are perceived by labor representatives as implicitly enhancing the stability of their own jobs.

5. By virtue of the division of tasks between the system of collective bargaining on the one hand, where employers' associations and the trade unions negotiate the base wage, and the system of works councils on the other, where the day to day operation of the working routines is being discussed, the works councils are relieved of those issues which necessarily would result in acrimonious disputes. Thus, the two systems mutually support each other.

6. Since labor representatives sit on the boards of corporations, the unions possess much more detailed information about specific companies than their American counterparts. They are therefore unlikely to overshoot in their bargaining, more inclined to take a long view and maximize lifetime earnings rather than per annum wages.

7. The first German post World War II parliament has given the hair thin majority of the governing coalition "an overwhelming majority", this result strikes me as a very important show of a consensus living in the post World War II West German democracy.

The families of the workers typically tied to the location, title needs to be given to all these stakeholders. Unions make these investments, because the investment they make in wage consessions can be guarded through the co-determination structures.

8. Very often, trade unions also guard the interests of the corporation in the towns where they 
operate. They thereby help in creating a business environment that is hospitable to the corporate activities.

9. The two tier board can function effectively because through the works councils information can be gathered in a systematic manner. The board is able to collect information which sometimes is not even available to management.

10. Since the supervisory board and the managing board are separate, the managing board is free to bargain with the unions, who are not represented there. A single tier system would not allow for this separation of interests.

11. The two tier system, again, helps in safeguarding investments against excessive demands of either side. This is true for both labor and capital.

12. Although through the corporate city tax (Gewerbesteuer) the German city is in fact a stakeholder in its corporations, and although the city is expected to furnish services from basics to schools, sometimes even theaters and symphony-orchestras, no attempt has been made to my knowledge to repeat the features of the Hesse organization act and grant the city seats on the supervisory board. The instrument that is used is typically a plain contract.

This contract a public contract, but many communities preferred contract privately through development boards (Entwicklungsgesellschaften).

13. Since bonding of investments is one of the key strategies used under co-determination, the works councils chairman have a specific role that is far beyond that of a shop steward, for instance, in the British system. They are selected not for their aggressive negotiation skills, impressive confrontational methods or rhetoric, but rather for guaranteeing smooth working relationships and an avenue for resolving the many conflicts that necessarily develop when people have to work together, certainly if highly committed and highly skilled people are involved.

14. Also collective bargaining is conducted differently when bonding of investments is a part of the set of strategies. Tactics need to be more subtyle not only in view of strike funds but also in view of human capital investments at stake.

15. Bonding is an attractive alternative strategy because the supervisory board allows for keeping an eye on the specific investments made.

16. Since bonding strategies are available, cities, in turn, are able to make long term commitments, which after all they have to finance out of tax revenues. These investments can go far beyond what is usually practiced in the United States by, for instance, a county development board. For instance, establishing schools, theaters, public pools and the like requires not only the initial investment, but also the continued commitment to cover the sometimes substantial operating costs.

17. Cities, through the works councils, often have a venue to press their wishes into firm decision makings as well. This is important when issues of city planning and work organization overlap (for instance bus schedules). Short communication lines can substantially cut 
transactions costs.

18. When a strike is being called, the mayor holds his breath. The city can loose twice, not only because of the reduced income and therefore likely increased level of entitlements that need to be paid out - in Germany the entitlements have to paid by the cities, not the state or the federal government - but also because depressed corporate revenues mean depressed corporate tax revenues, putting the city budget into a squeeze. It is obvious that through various channels a moderating influence is present.

19. Most cities in Germany operate a bank, the so-called Sparkasse. This is a leftover from traditional cameralist policies. These banking institutions also get involved, as they can in Germany, with locally operating companies, since commercial and investment banking can be done through one and the same institutions in the German banking systems. In this way, the city can exert an influence through the supervisory board if, as it is costumary, the major banks take seats on this board. The city mayor, in turn, typically appoints the bank manager. Often times, the city also relies to a not insignificant extent on the bank revenues for its own budgetary requirements.

20. Since the interest of the city and the workers (its citizens) co-incide to a large extent or are even parallel, the city where the company is operating is also interested in keeping the strategy of bonding investements viable. It tries to create an environment that makes the strategy attractive.

In this (as well as in many another unmentioned) way, the five pillars of co-determination support the entire structure in an interlocking way. Removing any one of them will lead to multifarious consequences, and these consequences are very difficult to predict beforehand.

\section{Legislation of Background Law and Deal Law}

The guiding hypothesis of this study had originally been the suspicion that ideological or specific political factors were decicive for co-determination to emerge in Germany and nowhere else. The parliamentary record, however, does not show such specific ideological or political considerations to have been important. Rather, despite some oddities of the political process, notably the trade unions' strike threat, co-determination appears to have been largely un-controversial. The previous section tried to show how the different elements of which codetermination is made up as an interlocking system fit together. This raises the different question of whether, under specific conditions, public choice processes can also lead to efficient legislation. To this issue we now turn.

The efficiency of the common law debate A steady flow of papers over the past two decades in the economie analysis of law suggests that the common law evolves toward efficiency ${ }^{12}$; the implication being that statute law does

12 Cooter \& Kornhauser 1980, Goodman 1978. Hirshleifer 1982, Landes \& Posner 1979, Posner 1977 (2), Priest 1977, and with reservations, Rubin 1977, 1982, Terrebonne 1981. There are others who disagree, e.g. Richard Posner is "distinctly 
not. Despite the different formulations, the suggestion turns on the proposition that inefficient law creates large transactions costs: hence, parties gain from having inefficient legal arrangements removed. It follows that inefficient legal rules will be litigated again and again, until they approach efficiency. Michelman (1980) showed that this tendency should hold for judicial behavior under either type of law, common or enacted. We should therefore observe a tendency toward efficiency in judicial rule making, independent of the particular legal culture in which a judge opines.

Whereas Michelman's amendment to the Posnerian argument considerably weakens the case for the superiority and singular efficiency of the common law, it refocuses attention on the body of law to which judicial decision making gives rise. That judicial decision making tends toward "efficient" (defined as wealth maximizing ${ }^{13}$ ) legal rules is quite consistent with another contention, dating back to Bentham ${ }^{14}$, that the common law, as a system of rules, lacks coherence and rationality and hence is less efficient than a code (one might add "can conceivably be"). The successive judicial decisions groping towards efficiency may reach a local optimum, an optimum that can be inferior to an inefficient solution reached otherwise. Further doubt is cast on the notion that the common law converges towards efficiency, since the supposition that inefficient rules will be relitigated rests on the assumption that the judiciary is a monopolistic provider of legal decisions. Inefficient legal arrangements need not be relitigated. Parties will engage in litigation only if each expects the benefits from litigation to exceed the costs. When inefficient verdicts are expected, parties will be reluctant to litigate and prefer rather to settle out of court. The tendency toward efficiency is not a dependable one. As Priest and Klein ${ }^{15}$ have shown, litigation depends largely on how close parties estimate the dispute to remain to the court's established decision standard. "Close" cases are most likely to be re-litigated, as are those in which one party has a relatively larger stake than the other. It follows that both efficient and inefficient decision rules can be perpetuated ${ }^{16}$. Disregarding for the moment private avenues of adjudication, it appears that whether the law is efficient will depend more on the performance of legislatures than the prevailing literature suggests. In this section I propose three variations of a simple model to show under which conditions we can expect a legislature to enact efficient law.

Three simple models

skeptical about the claim" (personal communication). The notion has nevertheless become so deeply rooted in the folklore of the law and economics subdiscipline that it has rendered meaningful discussions about efficient legislation by code or statute very, very difficult. The purpose of this section is to help overcome these mental obstacles.

See notably Posner 1981, the 1 ofstra Law Review Symposium 1, 111980 and, critically, Samuels 1981.

1780, Works 1838- Hart 1843, Collected Works 1968.

1984.

16 This begs a related question: Where will those parties turn that have been frustrated by inefficient court rulings? Answers to this question of substitute re-litigation will, of course, hinge on the availability of alternative sources of adjudication. 
In keeping with Michelman's (1980) distinction, we assume that there are two types of law in any society: law that every incremental enactment or judicial opinion build on ${ }^{17}$, and law that was a "deal" to redistribute income away from one group and toward another. In this transfer, the legislator is seen as a broker who acts for a fee ${ }^{18}$. "Deal law" may then be efficient in maximizing the wealth of the society in the long run, but it need not be. Conventionally, "background law" should tend toward efficiency, although my preceding remarks leave this supposition in doubt. "Background law" may be either common law or codified case law, consisting of pure codifications or a combination of these elements. Hence,

we can assume, in each jurisdiction, a certain amount of competition between the leglislature and the judiciary in providing "background law". While Michelman's distinction between "background law" and "deal law" is a straightforward one, identifying a particular piece of legislation as either being "background law" or "deal law" may be less so. It is perfectly possible that an act of parliament contains both. As Posner has pointed out, the distinction may require some deeper analysis in each individual case. He notes that "courts cannot readily identify purely redistributive legislation, in part because such redistributive legislation may be defensible on efficiency grounds by reference to problems of social peace, free rider problems and so forth ${ }^{19 "}$.

In this terminology, the question then can be put as follows: do we have to consider the codetermination legislation as background law, or rather as deal law? And if it is deal law, does it constitute an efficient deal or is it mainly of a re-distributive nature?

\section{A. Political Entrepreneurs}

Assume a legislature made up of representatives who broker their legislative services for a fee. They are individual wealth maximizers ${ }^{20}$.

The demand for legislative income transfers is fairly straightforward. It requires a group so small that the benefit bestowed upon it is clearly perceptible for each member; that is well organized so as to prevent dissipation of the benefit; and that is able to provide the brokerage fee in terms of either votes or pecuniary (and lawful) benefits.

The suppliers of wealth transfers, in turn, must be difficult to organize, and inelastic in their response to legislation. A threat of facing a one dollar loss as a consequence of legislation will not result in a one dollar increase in expenditure to fight such legislation; the individual expected costs of mounting a political defense exceed the expected individual gains (from not being coerced into a wealth transfer) and able to suffer the income loss. The opportunity costs

17 Michelman calls it "background law".

McCormick \& Tollison 1981.

See Richard A. Posner, The Constitution as an Economic Document. George Washington Law Review, 56 (1); November 1987, at note 12.

This assumption is standard in the American context. One should wonder whether it contains a reasonable description of political processes in Europe. In Europe, political parties tend to play a much greater influence than in the United States. Still, important interest groups are expediently and reliably being served by their parties or caucuses, and particular politicians specialize in particular interest groups. 
of resisting the wealth transfer must exceed the amounts (per person) transferred.

The more durable the enactment and the larger the transfer it provides, the more the receiving interest group is willing to pay. Yet, for the providing group, the more durable the enactment and the larger the transfer, the higher will be the benefit from resisting the transfer, whereas opportunity costs remain unaffected. Hence, wealth transfers are subject to a scale restriction that is determined by the (transactions) costs of resisting them. We should therefore observe multiple small transfers involving different groups of suppliers.

The main cost element facing groups that are either seeking or resisting wealth transfers are start-up costs, but once they are borne, they no longer affect marginal costs. Established interest groups, then, enjoy an advantage in both seeking and resisting wealth transfers. This advantage amounts to a strong incentive for an established clientele of transfer recipients. A transfer may be large and durable, yet only affect each supplier to a small extent. Still, the larger the group of suppliers end the larger or more durable the transfer (or both), the higher the benefits will be from resisting. Votes end wealth can be assumed to be convertible. Since brokers compete for wealth or votes, politica! entrepreneurs may seek out groups of suppliers and, in return for their votes, oppose transfer programs on their behalf. The larger the group of suppliers involved, or the larger or more durable the transfer sought, the higher the probability that a competing broker will organize resistance to a proposed wealth transfer. It follows that "deal law" should be of relatively shorter durability than "background law". Likewise, "deal law" should strongly benefit established groups and only mildly harm small, scattered groups; that is, "deal law" should not impose considerable welfare losses on the general public. There are clearly tendencies in society that contain the social loss from rent seeking ${ }^{21}$.

Assuming convertibility between wealth and votes, legislative brokers can either seek to serve established interest groups or appeal to large groups of general interest voters. They will probably do both; they have an incentive to produce legislation that benefits many while harming few. Generous transfers are largely precluded since a transfer that is perceptibly to benefit many must impose a heavy burden on a few. Such a transfer will not be supplied because the benefits from resisting it will generally exceed the opportunity costs of forgoing the resistance. It follows that legislative brokers have an incentive to produce legislation that is capable of producing wealth for the general public; the more durable this wealth-producing legislation is, the larger the benefit is from it and, presumably, the larger the expected return in votes. Legislators face incentives to produce durable wealth-enhancing legislation side by side with incentives to broker transfers of relatively limited duration. This holds true under the assumption that legislators have sufficient information. While obviously legislators are not omniscient, they can rely on their clients to possess and process the relevant information. Wealth reducing legislation will be brought to the attention of the legislators by those whose wealth is being affected as well as the press.

We conclude that brokers in the legislature face incentives to produce both efficient "background law" as well as (mildly) inefficient "deal law". "Mildly" inefficient is a deliberately loose term, since the argument is cast in terms of tendencies, not precisely quantifiable magnitudes. I mean to suggest that the (negative) welfare costs of deal law in this scenario will be relatively minor as composed to the (positive) welfare effects of background law. 


\section{B. The Open Jurisdiction}

The second model differs from the first in two respects. It assumes that the jurisdiction is open in the sense that citizens and corporations can either resist or evade unwanted legislation. They may evade into other jurisdictions or into an extralegal domein within the jurisdiction, such as an underground or shadow economy. The first alternative is relatively straightforward, the equivalent to the small open economy in international trade theory. The smaller the jurisdiction and the more flexible the agents it comprises, the more elastic we can expect the evasive response to be. Even if the jurisdiction is "big" and closed, however, the room for evasion may be substantial. Regulations can be avoided by taking up other lines of business. Conflicts can routinely be settled out of court or conflict prone transactions can be avoided altogether. Alternative forms of dispute resolution can be resorted to or initiated. Finally, producers can withdraw from market transactions and shift exchanges of goods and services into an organization designed to reduce transactions costs ${ }^{22}$.

None of these developments are included in what has been labeled the shadow economy, which itself is reputed to be a sizable extralegal sector in the advanced Western economies ${ }^{23}$. The shadow economy, then, can be assumed to provide scope for evasion in addition to the evasion strategies already listed above ${ }^{24}$.

This modification of our model has two implications: the larger the potential is to evade, the smaller the citizens' incentive will be to resist "deal" law that aims at extracting transfers, and the smaller the extracted transfer, particularly in the long run. While this leaves the demand for transfers unaffected, increasing the scope for evasion dries up the supply and raises the legislators' cost of providing transfers, or "deal laws".

Secondly, the larger the scope for evasion, the stronger the competitive pressure will be on legislators to produce efficient legal arrangements. And the stronger those competitive pressures are, the more likely it is that the economy will experience an expansion of its production possibility frontier.

The efficiency effect of "deal law" when supply dries up is essentially secondary, that is, that efficiency loss occurs in terms of productive activities foregone in an economy. These are the opportunity costs of "deal law". Obviously, they depend on the extent to which opportunities for wealth production are foreclosed by "deal law". This effect implies that the general welfare loss of "deal law" increases with the scope for evasion.

Where resistance to "deal law" weakens and transfers decline, a large number of "deal laws" will be enacted. This observation reinforces the aforementioned tendency for "deal laws" to be numerous but of relatively limited direct impact on attained wealth. By the same reasoning, however, "deal laws" contract the production possibility frontier of the economy at large and hence affect citizens' attainable wealth positions.

We can conclude that in an "open" jurisdiction, legislators face even stronger incentives to produce efficient "background law", whereas incentives to produce "deal law" become weaker relative to the first model.

\section{Introducing Leviathan}

$22 \quad$ Williamson 1981.

23 Simon \& Witte 1982, Tanzi 1982.

$24 \quad$ Frey \& Ramser 1983, Frey \& Weck 1983. 
The third model expands on the second in featuring an open juridiction, a Leviathan legislature ${ }^{25}$ that seeks to maximize revenues from taxation, end a judiciary that adjudicates litigation by professional standerds of jurisprudence end remains unaffected by the revenue maximization behavior of the legislature. Hence, an independent judiciary is assumed. Model C is designed to the long-run implications of legislators' activities on the efficiency of the whole body of law.

In Leviathan models legislators are again assumed to maximize political profits from taxation, on the one hand, or regulation (i.e. "deal law") on the other. Taxation and regulation are not only interchangeable as political means. Inasmuch as policies based on either invariably burden the citizenry, the size and fertility of the tax base is affected by the extent of regulation ${ }^{26}$; whereas conversely the regulatory domein shrinks as the burden of taxation increases, and vice versa: reducing the burden of taxation opens up the regulatory domain. From this simple argument it follows that the production of "deal law" impairs the fertility of the tax base. Hence, "deal laws" generate negative externalities for the legislature at large by reducing the tax pie.

In the Leviathan literature ${ }^{27}$ it is customary to assume that Leviathan acts myopically. The long-run tax rate is assumed to exceed that rate which would yield the maximum stream of tax revenues; likewise the long-run regulatory intensity exceeds that regulatory intensity which would maximize the production of "deal law" in the long run. Frey and Ramser ${ }^{28}$ have shown, however, that the short run optimization of tax rates as welf as regulatory intensities (considered simultaneously) can yield overregulation in tandem with undertaxation. It then appears that Leviathan's myopia is at odds with the beast's appetite. Shortrun optimization does not yield a maximum political profit.

By way of clarification suppose there is a unicameral legislature ${ }^{29}$ and delegates are allowed to be reelected. Then we can classify the delegates into cohorts according to the length of their tenure in the legislature. Whereas seniority can safely be assumed to carry additional power, there will always be a cohort that contains more members than a given one chosen at random. The larger cohort will be composed of younger delegates than the smaller one. This rule applies to all but the youngest cohort, which will be the largest. Hence, votes tend to be concentrated with younger delegates. The longer the tenure of a delegate, the shorter his expected future tenure, and thus the shorter his time horizon can be in taking political decisions. Empirically we also observe that elected officials' reelection probabilities are a

$25 \quad$ Buchanan \& Brennan 1980.

26 Posner, 1986. The trade-off has long been noted in the economics literature. See Backhaus \& Wagner 1987.

$27 \quad$ Buchanan \& Brennan 1980, Buchanan \& Lee 1982. 1983.

According to McCormick \& Tollison 1981, a unicameral legislative is more conducive to interest group, i.e. "deal law" legislation than a bicameral legislature, especially if the two houses are of uneven size. 
positive function of the length of their past tenure.

The relatively lower reelection chance of younger representatives affects the length of their time horizon only insofar as political gains and losses of "deal law" can be more heavily discounted in the immediate future where reelection is uncertain. Long run effects, however, will be important for younger elected officials who can expect to be held responsible for "deal" legislation they supported. Hence, elder delegates should be observed to be more prone to "deal law" than younger delegates. Conversely, the "newcomers" are more likely to take a long-run view, since they stand a greater chance not only of being confronted with the adverse consequences of sizing down the tax base of regulatory domain but of profiting individually from a large future tax base and unimpaired regulatory domains. Their opportunity cost of exposing deals is lower than that of longer serving legislators; it may even be nil. Since powerful interest groups will turn primarily to senior legislators who can deliver better deals, exposing those deals may be the best strategy in trying to depose long serving incumbants. Thus, gains from exposing "deal law" and introducing "background law" are likely to be highest for junior candidates, even if their expected tenure in office may remain relatively low due to lower (re-)election chances. In turn, delegates who take a longterm view outnumber their elder colleagues; more particularly, they have an incentive to produce "background law" that broadens the tax base and increases its fertility by expanding the production possibility frontier of the economy. All this suggests that "deal laws" will often be opposed by younger politicians who try to build political coalitions of transfer victims, thus seeking votes in the present while preserving their political power base for the future. This tendency should be observable in particular where politicians can claim revenue sources or regulatory domains, i.e., when political property rights are allowed to develop.

\section{Concluding remarks}

Will democratic legislatures largely engage in producing "deal law" at the expense of providing the economy with "background law"? Under the strict assumptions that legislatures consist of political brokers who act in a Leviathan environment, the conclusion is a resounding no. Brokers in the legislatures face incentives to produce efficient "background law" as well as (mildly) inefficient "deal law".

Although these incentives hold in a closed jurisdiction, in an open jurisdiction, legislators face even stronger incentives to produce efficient "background law", whereas incentives to produce "deal law" become weaker relative to the first model. Finally, taking a long-run view, one notes that "deal laws" will often be opposed by younger politicians who try to build political coalitions of transfer victims, thus seeking votes in the present and preserving their political power base for the future. This tendency should be observable in particular where politicians can claim revenue sources or regulatory domains, i.e., when political property rights are allowed to develop.

\section{Application to the Legislation of Co-determination Structures.}

In the previous section, we have shown that under standard public choice assumptions, it is quite likely that efficient law is being legislated. Hence, even holding on to strict public choice assumptions does not lead to the suggestion that inefficient or re-distributive legislation is likely. If, as in the case of the Federal Republic of Germany when deciding on co-determination structures, the jurisdiction had to be assumed as open and companies could easily avoid the 
application of the legislation, it is extremely likely that members of parliament faced strong incentives to produce efficient law. Not only the legislative history but also standard public choice analysis points in the direction of this conclusion.

\section{The Paradox of Monitoring}

The theory of the classical firm assigns one factor of production, typically capital, the role to assign the monitor of on the one hand its own performance and secondly the performance of the other factor, i.e. labor. Monitoring is in itself a productive task, since it prevents shirking, that is a sub-optimal use of the means of production, typically in the interest of one of those involved in the process of production but not co-incident with the purpose of the operation. Williamson calls this the problem of sub-goal pursuit. The marginal productivity of either factor of production, both labor and capital, depends on managerial services, and in particular the marginal productivity of labor depends on managerial inputs, as the marginal productivity of management depends on the willingness of workers to be efficiently managed. The marginal productivity of either one of these factors determines, ultimately, its remuneration. Both wages and managers' earnings depend, ultimately, on their marginal productivity, measuring errors notwithstanding. Hence, when in both line work and management there is an element of discretion, a system of monitoring needs to be found that does not depend on any one of these factors.

If we look at the situation as it existed in West Germany in 1949 when the newly elected government with its hair thin majority announced its intent on passing the legislation that would introduce co-determination, setting up an efficient governance structure amounted to a substantial organizational and legislative challenge. Six elements of that situation stand out to be mentioned:

1. To begin with, German companies in 1949 had virtually no access to international capital markets. Since there were no local capital markets either, investments had to be made out of profits not yet realized. These profits, in turn, obviously depended on the size of investment. The larger the investment could be, the larger could be the marginal and total productivity of labor, and hence the wage. However, no capital markets being available and investments having to be paid out of gains not yet being made, the larger the net profits of the firm the larger the wage, but the larger the wages fund the smaller the net profits of the firm and hence the smaller the investments to be made and hence the smaller the marginal productivity of labor. This strange paradox called for a resolution.

2. Due to both the war destruction and the ensuing demountation campaigns, many firms found themselves with insufficient or no equipment. The firms book assests having been reduced by war and ensuing inflation, currency reform and depreciations to next to nothing, the real assests consisted in the firm's history, a site which often resembled a pile of rubble, and a willing work force. The history also included the memory of how to produce, of how to organize, how to link up with former suppliers and customers, and how to work with the local government.

3. Some of these former customers, however, were not currently available. German companies had to re-establish their previous international customer relationships, itself a time consuming process, and a difficult one as due to the war, technological advances had not been realized in 
civilian production.

4. The reputation of those former owners and managers was often tainted. Immediately after the war, some of the owners had been detained in camps, what had been a business relationship with the government was now seen as criminal complicity. Hence, often times firms also lacked the credit that they had hitherto enjoyed through the reputation of their owners. Partly, the new managers who had to a large extent also been recruited from the labor movement formed a part of the reputation on which credit could be extended.

5. On the other hand, firms in 1949 invariably met strong market demand, as citizens were trying to rebuild their lives, as either refugees or survivors of the bombing raids. Many people had lost their household possessions and were eager to rebuild a normal life. The strong materialism characteristic of the fifties and sixties in Germany bears ample witness to these initial shortages.

6. Finally, political life was reconstituting itself from the bottom up. Only in 1949 had a limited federal government been formed. In 1945, first local, then regional and later state governments had been formed. Only the year of 1948 saw the currency reform with the emergence of markets. In 1949, the war and post war period was still very much dominating peoples' minds, the experience with the newly created market, in many ways the first free market after 1914, was still very fresh and equally short.

What then is the appropriate governance structure of corporations to rise out of these precarious conditions? It is obvious that the classical firm, under these conditions, is not the appropriate answer. The monitors themselves needed to be monitored.

\section{The Solution of Bonding}

Under these circumstances, both owners and workers with their representatives had an interest in rebuilding the companies and creating an investment fund through wage restraint. Thereby, of course, the workers had to become co-owners, but the solution suggested by the Free Democrats of gradually giving them ownership certificates such as stock in exchange for wage consessions was not a feasible alternative, since co-monitoring of the investment had to start right away. How could the workers have accepted stock in worthless companies that could only gain in value through their commitment to create credit? The solution suggested by the (legally trained - all four had a doctorate) managers in 1947 indeed was a stroke of genious. By building on the concept of the two tier board, labor could be invited to assume an equal position on the supervisory board and management could proceed, as professionally as possible, under the joint supervision of labor and capital. In fact, the investment of the workers had been bonded. Only through the bonding process was it indeed forthcoming. In this sense, co-determination can be assigned an important rank in explaining the "economic miracle" West Germany lived through in the fifties and sixties. ${ }^{30}$

30 An American commentator has cast the matter alternately; the workers, afraid of future stock emissions and thereby a dilution of their shares, preferred the statutory board seats to shares. This may be a good start for didactical purposes. Yet, German 
The stark consensus that marked the position of all parties in the parliamentary debate thereby finds its logical explanation. The situation required a new solution which was indeed hit upon, and there was no relevant alternative. This, however, may be said not to have been true afterwards. To that question we now finally turn.

\section{Path Dependence}

Ultimately, the question needs to be addressed as to why the institution of co-determination was not only continued but also extended to cover the entire German corporate landscape (of companies having more than 1,000 employees).

The answer has to be given in different parts. To start with, two common misperceptions have to be avoided. The first misperception concerns the firm's capital access at the time when codetermination was introduced. Henry Hansmann ${ }^{31}$ writes: "I can, however, hazard a theory of my own: that the firms involved would probably have to raise new capital at some point, and that they might want to sell large amounts of stock for the purpose - stock that would dilute the worker's earnings and control.

Co-determination assured them 50\% control, and through that control they could assure themselves wages yielding an appropriate fraction of the companies' earnings." (p. 2)

This alternate theory is factually wrong on two points. First, companies for some time to come had no access to capital markets and therefore had to rely on self-financing. International capital markets were not accessible to German corporations (at the time of the deliberations still suffering under demountations), and domestic capital markets were extremely thin during the first part of the fifties.

Secondly, co-determination did allow workers control over the investments in terms of siting and (through co-decision making in the works councils) the technologies used, and therefore could indeed have been used in order to shape any specific capital increases through issuing new stocks or bonds. Co-determination, however, does not allow any access to decisions over wages.

Hence, in order to explain the further extension of co-determination, we have to stick to the specific German case which is not generalizable as it depends on a historical starting point not to be found anywhere else in the industrialized world.

The first part concerns the act of 1965, which was part of the corporate reform act needed because the national socialist government had written the leader principle into corporate law. This complicated reform package also included all those element of co-determination that the speaker of the Free Democratic Party in the parliamentary debate had outlined in 1951,

companies tend not to rely on stock issuance, for their expansions, not even today, and certainly not then (in 1951) when there were yet no viable capital markets.

31 "Comments", Conference on Employees and Corporate Governance. Columbia Law School, November 22, 1996. 
including the one third representation of labor in the supervisory boards. That act covers every joint stock company with more than 1,000 employees.

Different is the act of 1976, which was the result of the big coalition between the original two large parties that had in 1949 supported co-determination, although only one of them had been part of government. The price for taking part in government that the Social Democrats exerted was the extension of co-determination over all industries beyond coal and steel. Here, the echelon was finally decided to be a minimum of 2,000 employees. However, Biedenkopf already in 1965 had found that co-determination in the industries covered worked in that it did not lead to frictions and conceivably had benefits. Since 1965, companies were aware of the pending legislation. Easy escape routes were built early on. The act requires specifically corporate forms which can be changed, it is bound to a specific size which can be undercut by re-proportioning or re-grouping enterprises, it requires a location of the seat of the company within the German jurisdiction which can be easily avoided (for instance by locating headquarters in German language Switzerland), even a simple change in the by-laws of the supervisory board can render co-determination under the act of 1976 meaningless. All of these activities took place to a certain extent, but not to a very large extent. When the act passed in 1976 with more than $90 \%$ of the vote in parliament, and without even a hint of union action, it was widely perceived as a logical evolutionary development in German corporate law. No perceptible effect on the stock exchange has ever been documented. There was litigation surrounding the implementation and there was litigation in front of the constitutional court in order to test the future of such legislation. However, the general perception is that there is not going to be a future in this legislation. Co-determination as a part of German corporate law is firmly in place, and the only point of further argument is to defend it against future developments in corporate law initiated by the European Commission or the European Parliament. Since under the Maastricht Treaty, that treaty has to be read through the German Basic Law, and since co-determination has been tested against the German Basic Law, through the constitutional court case against the co-determination act of 1976 and the ensuing verdict, co-determination has been chiseled in stone for the time being and under the restrictions mentioned above.

The further development of co-determination after 1951 can only be partly seen as path dependent. The other and more important part is the experience the German industry has gained with the institution of co-determination, and that experience has not varied much from the original conditions. Since in Germany the different stakeholders are expected to invest heavily in the company, the stakeholders including the workers, the local community, capital owners, of course, title needs to be given to all these investment commitments. Since such title is difficult to imagine, co-determination may have proven to be the most adequate vehicle to protect investments that can be jeopardized when industrial strife, antagonism, intolerance or managerial hybris endanger specific assests, these being either specific human capital investments or specific capital investments.

\section{Conclusion}

In this essay, I have tried to render an account of the history of German co-determination from the point of view of why it actually came about. The essay tries to suggest that the solution, although innovative, was virtually the only one German decision makers in both industry, trade 
and politics could hit upon. As it turns out, the solution was suggested, independently or not, by four academically trained industry leaders in the industrial heartland of West Germany.

Although the implementation through various legislatures of the solution required a circuitous route, the final outcome seems logical enough. However, it is an outcome that has a very specific origin. It is not clear under which circumstances German co-determination could be an interesting or even an attractive model for corporate America. 


\section{REFERENCES}

ACKERMAN, Bruce A. (1983), Reconstructing American Law, Cambridge, Harvard University Press.

BACKHAUS, Jürgen G. \& WAGNER, Richard E. (1987), "The Cameralists: A Public Choice Perspective", Public Choice, 53, pp. 3-20.

BACKHAUS (1979), “Ökonomik der partizipativen Unternehmung I.” Tübingen:

Mohr/Siebeck 1979, xiv + pp. 394.

BACKHAUS/NUTZINGER (Eds.), Co-determination: A Discussion of Different Approaches.

Heidelberg and New York: Springer Press 1989 (295 pp.).

BAINBRIDGE, Stephen, (1996), "Participatory Management Within a Theory of the Firm", The Journal of Corporation Law, vol. 21, nr. 4.

BENTHEM, Jeremy, An Introduction to the Principles of Morals and Legislation (printed 1780, published 1978); Of Laws and General (written before 1789, published 1970); The Works of Jeremy Bentham (11 Volumes), Bowering, (Dir.), Edinburgh 1838-1843; The Collected Works of Jeremy Bentham, London, 1968.

BÖHM, "Das wirtschaftliche Mitbestimmungsrecht der Arbeiter im Betrieb", ORDO IV, 1951 BUCHANAN, James M. \& BRENNAN, Geoffrey (1980), The Power to Tax. Analytical Foundations of a Fiscal Constitution, Cambridge, Cambridge University Press.

BUCHANAN, James M. \& LEK, Dwight R. (1982), "Politics, Time, and the Laffer Curve", Journal of Political Economy, 90, pp. 816-819.

COOTER, Robert \& KORNHAUSER, Lewis (1980), "Can Litigation Improve the Law Without the Help of Judges?", Journal of Legal Studies, 9, pp. 139-163.

FREY, Bruno S. \& RAMSER, Hans Jürgen (1986), "Where are the Limits of Regulation?" Journal of Institutional and Theoretical Economics 142, pp. 571-580 (Zeitschrift fur die gesamte Stuatswissenschaft).

FREY, Bruno S. \& WECK, Hannelore (1983), "What Produces a Hidden Economy? An International Cross Section Analysis", Southern Economic Journal, 49, pp. 822-832.

GOODMAN, John C. (1978), "An Economic Theory of the Evolution of the Common Law", Journal of Legal Studies, 7, pp. 393-406.

HANSMANN, Henry, (1996), "Comments", Conference on Employees and Corporate Governance. Columbia Law School, November 22.

HART, H.L.A. (1982), Essays on Bentham, Studies in Jurisprudence and Political Theory, Oxford, Clarindon Press.

HIRSHLEIFER, Jack (1982), "Evolutionary Models in Economics and the Law: Cooperation versus Conflict Strategies", Research in Law and Economics, 4, pp. 1-60.

LANDES, William M. \& POSNER, Richard A. (1979), "Adjudication as a Private Good", Journal of Legal Studies, 8, pp. 235-284.

MICHELMAN, Frank I. (1980), "Constitutions, Statutes, and the Theory of Efficient Adjudication". Journal of Legal Studies, 9, pp. 431-461.

McCORMICK, Robert E. \& TOLLISON, Robert D. (1981), Politicians, Legislation, and the Economy. An Inquiry into the Interest Group Theory of Government, Boston/The Hague, Martinus Nijhoff.

POSNER, Richard A. ( 1 986)(3rd), The Economic Analysis of Law, Boston, Little Brown. POSNER, Richard A. (1981), The Economics of Justice, Cambridge, Harvard University Press.

POSNER, Richard A. (1987), "The Constitution as an Economic Document", George Washington Law Review, 56 (1), November. 
PRIEST, George L. (1977), "The Common Law Process end the Selection of Efficient Rules", Journal of Legal Studies 6, p. 65.

PRIEST, George L. (1980), "Selective Characteristics of Litigation", Journal of Legal Studies, 9, p. 399.

PRIEST, George L. \& KLEIN, Benjamin (1984), "The Selection of Disputes for Litigation", Journal of Legal Studies, 13, pp. 1-55.

RUBIN, Paul H. (1977), "Why is the Common Law Efficient?", Journal of Legal Studies, 6, pp. 51-63.

RUBIN, Paul H. (1982), "Common Law end Statute Law", Journal of Legal Studies, 1 1, pp. 205-225.

SAMUELS, Warren (1981), "Maximization of Wealth as Justice", Texas Law Review, 60, pp. 147- 172.

SIMON, Carl P. \& WITTE, Ann D. (1982), Beating the Systems: The Underground Economy, Boston, Auburn House.

TANZI, Vito (Ed.) (1982), The Underground Economy in the United States and Abroad, Lexington, Heath.

TERREBONNE, R. Peter (1981), "A Strictly Evolutionary Model of Common Law", Journal of Legal Studies, 10, pp. 397-407.

TULLOCK, Gordon (1980), "Efficient Rent Seeking", in: Buchanan, Tollison \& Tullock (Eds.), Toward a Theory of the Rent Seeking Society, College Station, Texas A \& M University Press, pp. 3-15.

WILLIAMSON, Oliver E. (1981), "The Modern Corporation: Origins, Evolution, Attributes", Journal of Economic Literature, 19, pp. 1537-1570. 